\title{
Optimization of Culture Medium Enhances Viable Biomass Production and Biocontrol Efficacy of the Antagonistic Yeast, Candida diversa
}

\author{
Jia Liu', Guangkun $L i^{2}$ and Yuan Sui ${ }^{1 *}$ \\ ' Chongqing Key Laboratory of Economic Plant Biotechnology, Collaborative Innovation Centre of Special Plant Industry in \\ Chongqing, College of Forestry and Life Science, Institute of Special Plants, Chongqing University of Arts and Sciences, \\ Chongqing, China, ${ }^{2}$ School of Food Science and Engineering, Hefei University of Technology, Hefei, China
}

\section{OPEN ACCESS}

Edited by:

Giovanna Suzzi,

Università di Teramo, Italy

Reviewed by:

Xiaodong Zheng,

Zhejiang University, China

Silvana Vero,

University of the Republic, Uruguay

${ }^{*}$ Correspondence:

Yuan Sui

suiyuan-mine@163.com

Specialty section: This article was submitted to

Food Microbiology,

a section of the journal

Frontiers in Microbiology

Received: 11 July 2017 Accepted: 03 October 2017 Published: 17 October 2017

Citation:

Liu J, Li G and Sui Y (2017)

Optimization of Culture Medium Enhances Viable Biomass Production and Biocontrol Efficacy of the Antagonistic Yeast, Candida diversa.

Front. Microbiol. 8:2021. doi: 10.3389/fmicb.2017.02021
Viable biomass production is a key determinant of suitability of antagonistic yeasts as potential biocontrol agents. This study investigated the effects of three metal ions (magnesium, ferrous, and zinc) on biomass production and viability of the antagonistic yeast, Candida diversa. Using response surface methodology to optimize medium components, a maximum biomass was obtained, when the collective $\mathrm{Mg}^{2+}, \mathrm{Fe}^{2+}$, and $\mathrm{Zn}^{2+}$ concentrations were adjusted in a minimal mineral (MM) medium. Compared with the unmodified MM, and three ion-deficient MM media, yeast cells cultured in the three ion-modified MM medium exhibited a lower level of cellular oxidative damage, and a higher level of antioxidant enzyme activity. A biocontrol assay indicated that $C$. diversa grown in the ion-modified MM exhibited the greatest level of control of gray mold on apple fruit. These results provide new information on culture medium optimization to grow yeast antagonists in order to improve biomass production and biocontrol efficacy.

Keywords: antagonistic yeast, antioxidant system, biocontrol activity, biomass, medium optimization

\section{INTRODUCTION}

A variety of fungal pathogens cause post-harvest diseases on fruits, vegetables and grains, which result in significant economic losses. Some post-harvest diseases also represent a potential health risk to humans, as certain decay fungi produce mycotoxins (Yang et al., 2015; Liu et al., 2017). Currently, synthetic fungicides are still the main method used to manage post-harvest decay. Increasing concerns about environmental and food safety have generated a great interest in the development of alternative control methods (Mari et al., 2014). Biological control, utilizing antagonistic yeasts, has been proposed as an effective and eco-friendly alternative. Research on this approach has been actively pursued over the past 30 years, and a few yeast-based biocontrol products are commercially available (Liu et al., 2013a; Sui et al., 2015; Spadaro and Droby, 2016; Wisniewski et al., 2016). Several species of yeast in the genus Candida, including C. diversa (Li et al., 2016), C. sake (Marín et al., 2016), C. oleophila (Liu et al., 2013b) and C. saitoana (El Ghaouth et al., 2003), have been reported as effective post-harvest biocontrol agents.

Commercial production of biocontrol agents need to produce sufficient biomass in an economic manner. In addition, formulated products must have adequate shelf life, while retaining biocontrol efficacy (Liu et al., 2009; Melin et al., 2011). The ability to achieve these goals requires low-cost medium components that produce a maximum level of viable biomass. In this regard, metal ions 
in a medium are required to sustain certain biochemical reactions important in the growth and viability of yeast. Thus, they play a critical role in biomass production and maintaining viability (Poreda et al., 2013). Magnesium, ferrous, and zinc ions, can significantly impact enzyme activity, lipid synthesis, biomass accumulation, and viability (Jernejc and Legiša, 2002). For example, Stehlik-Tomas et al. (2004) reported that the addition of zinc, copper, and manganese sulfate to a molasses-based medium enhanced the biomass yield of Saccharomyces cerevisae up to $30 \%$ under semi-aerobic conditions.

The current study evaluated the ability of the addition of metal ions to a minimal mineral medium (MM) to maximize biomass production of the antagonistic yeast, $C$. diversa. The study investigated the effect of $\mathrm{Mg}^{2+}, \mathrm{Fe}^{2+}$, and $\mathrm{Zn}^{2+}$ ions on (i) viable biomass production; (ii) amelioration of oxidative damage to proteins and lipids, and the enhancement of antioxidant enzyme activity; and (iii) the biocontrol efficacy of $C$. diversa against gray mold on apple fruit caused by Botrytis cinerea.

\section{MATERIALS AND METHODS}

\section{Fungal Pathogen}

The fungal pathogen, B. cinerea, was isolated from infected apple fruit and maintained on potato dextrose agar (PDA). To reactivate the culture and verify its pathogenicity, the pathogen was inoculated into wounded apple fruit and re-isolated onto PDA once an infection was established. B. cinerea spore suspension was obtained from 2-week-old PDA cultured at $25^{\circ} \mathrm{C}$. Spore concentration was determined using a hemocytometer and adjusted to $10^{4}$ spores $/ \mathrm{mL}$ with sterile distilled water.

\section{Fruit Host}

Apple fruits (Malus x domestica Borkh. cv. Fuji) were harvested at commercial maturity. Fruits without wounds or rot were selected based on uniformity of size. The selected fruits were disinfected with $2 \%(\mathrm{v} / \mathrm{v})$ sodium hypochlorite for $2 \mathrm{~min}$, rinsed with tap water, and air-dried prior to their use in the biocontrol assays.

\section{Yeast Strain and Growth Conditions}

The yeast, C. diversa L-198, was isolated from the surface of plum fruit ( $\mathrm{Li}$ et al., 2016). C. diversa was cultured at $25^{\circ} \mathrm{C}$ for $48 \mathrm{~h}$ on yeast peptone dextrose agar (YPDA, $10 \mathrm{~g}$ of yeast extract, $20 \mathrm{~g}$ of peptone, $20 \mathrm{~g}$ of dextrose, and $2 \%$ agar in $1 \mathrm{~L}$ of water). A flask culture (20 mL in 100-mL conical flask) of a single colony was carried out in sterilized liquid YPD medium overnight as a seed culture. The seed culture was centrifuged and washed twice using sterile water, and then transferred to a MM media (Fan et al., 2013) at an initial concentration of $3 \times 10^{6}$ cells $/ \mathrm{mL}$. On a per liter basis, the MM was composed of: $0.5 \mathrm{~g} \mathrm{MgSO}_{4} \cdot 7 \mathrm{H}_{2} \mathrm{O}$, $3.0 \mathrm{mg} \mathrm{FeSO} \cdot \cdot 7 \mathrm{H}_{2} \mathrm{O}, 4.5 \mathrm{mg} \mathrm{ZnSO}_{4} \cdot 7 \mathrm{H}_{2} \mathrm{O}$, $5.0 \mathrm{~g}\left(\mathrm{NH}_{4}\right) \mathrm{SO}_{4}$, $3.5 \mathrm{~g} \mathrm{KH}_{2} \mathrm{PO}_{4}, 15.0 \mathrm{mg}$ EDTA, $4.5 \mathrm{mg} \mathrm{CaCl} \cdot 2 \mathrm{H}_{2} \mathrm{O}, 1.0 \mathrm{mg}$ $\mathrm{H}_{3} \mathrm{BO}_{3}, 0.4 \mathrm{mg} \mathrm{Na} \mathrm{MoO}_{4} \cdot 2 \mathrm{H}_{2} \mathrm{O}, 0.3 \mathrm{mg} \mathrm{CoCl} \cdot 2 \mathrm{H}_{2} \mathrm{O}, 0.3 \mathrm{mg}$ $\mathrm{CuSO}_{4} \cdot 5 \mathrm{H}_{2} \mathrm{O}, 0.1 \mathrm{mg} \mathrm{KI}, 50 \mathrm{ug}$ D-biotin, $0.2 \mathrm{mg} p$-aminobenzoic acid, $1.0 \mathrm{mg}$ nicotinic acid, $1.0 \mathrm{mg}$ calcium pantothenate, $1.0 \mathrm{mg}$ pyridoxine $\mathrm{HCl}, 1.0 \mathrm{mg}$ thiamine $\mathrm{HCl}$, and $25.0 \mathrm{mg}$ myoinositol. Glucose $(20 \mathrm{~g} / \mathrm{L})$ was added as a carbon source. All media were adjusted to $\mathrm{pH} 5.0$ before seed cultures were added. The yeast cultures were grown in $200 \mathrm{ml}$ in a 1-L conical flask shaken at $200 \mathrm{rpm}$ and kept at $28^{\circ} \mathrm{C}$.

\section{Response Surface Methodology (RSM) for Optimizing Medium Components}

Five initial concentrations of $\mathrm{Mg}^{2+}(0,500,1000,1500$, and $2000 \mathrm{mg} / \mathrm{L}), \mathrm{Fe}^{2+}(0,1.2,2.2,3.2$, and $4.2 \mathrm{mg} / \mathrm{L})$, and $\mathrm{Zn}^{2+}$ $(0,3,26.5,50$, and $73.5 \mathrm{mg} / \mathrm{L})$ were evaluated in single factor experiments, in order to determine maximum biomass production of the yeast after 96 -h of culture. The concentrations of $\mathrm{Mg}^{2+}, \mathrm{Fe}^{2+}$, and $\mathrm{Zn}^{2+}$ gaining each maximum biomass served as non-code variables of $\mathrm{A}, \mathrm{B}$, and $\mathrm{C}$, respectively. The code variables of $\mathrm{X}_{1}, \mathrm{X}_{2}$, and $\mathrm{X}_{3}$ were transformed from non-code variables as follows, $\mathrm{X}_{1}=(\mathrm{A}-1500) / 500, \mathrm{X}_{2}=(\mathrm{B}-2.2) / 1$, $\mathrm{X}_{3}=(\mathrm{C}-26.5) / 23.5$ (Table 1). Based on the data of the single factor experiments, a three-factor $\left(\mathrm{Mg}^{2+}, \mathrm{Fe}^{2+}\right.$, and $\left.\mathrm{Zn}^{2+}\right)$ Box-Behnken design with 17 experimental runs was generated using DesignExpert ${ }^{\text {TM }}$ V.10 software (Hallenbeck et al., 2015). A quadratic polynomial equation was fitted to data in order to correlate the relationship between the independent variables and responses. RSM provided the ability to predict the optimum concentration of metal ions needed to provide maximum biomass production of the yeast.

\section{Analysis of Biomass and Viability}

The unmodified $\mathrm{MM}$, and the $\mathrm{Mg}^{2+}, \mathrm{Fe}^{2+}$, and $\mathrm{Zn}^{2+}$-deficient MM media were compared to the previously determined optimized medium. Yeast samples, cultured in the media described above, were collected after 96-h of culture, pelleted at $8,000 \mathrm{~g}$ for $3 \mathrm{~min}$, and washed twice with sterile distilled water to remove residual medium. The samples were then divided two groups to determine dry biomass and cell viability, respectively.

Biomass was assessed as dry weight (g) per liter of culture medium $(\mathrm{g} / \mathrm{L})$. Specifically, yeast samples from $1 \mathrm{~L}$ of culture medium were oven-dried at $60^{\circ} \mathrm{C}$ until a stable weight was achieved. Yeast viability was determined using the methylene blue technique (Alfenore et al., 2002). A $200 \mu \mathrm{L}$ sterile solution of methylene blue $\left(0.3 \mathrm{mM}\right.$ in $68 \mathrm{mM} \mathrm{Na}_{3}$ citrate) was mixed with $200 \mu \mathrm{L}$ of a yeast suspension and then diluted to reach an $\mathrm{OD}_{620} \mathrm{~nm}$ of $0.4-0.7$. The mixture was shaken and, after $5 \mathrm{~min}$ of incubation, placed in a cell counting chamber. The number of stained and unstained yeast cells was separately counted in five different microscopic fields achieving a total of at least 200-300

TABLE 1 | Levels of the code values and none code values based on single factor (ion) experiments.

\begin{tabular}{lccccc}
\hline Independent variables & Code & None code & \multicolumn{3}{c}{ Code levels (mg/L) } \\
\cline { 3 - 6 } & & & $-\mathbf{1}$ & $\mathbf{0}$ & $\mathbf{1}$ \\
\hline $\mathrm{Mg}^{2+}$ & $\mathrm{X}_{1}$ & $\mathrm{~A}$ & 1000 & 1500 & 2000 \\
$\mathrm{Fe}^{2+}$ & $\mathrm{X}_{2}$ & $\mathrm{~B}$ & 1.2 & 2.2 & 3.2 \\
$\mathrm{Zn}^{2+}$ & $\mathrm{X}_{3}$ & $\mathrm{C}$ & 3.0 & 26.5 & 50.0
\end{tabular}

The relations between the code values and none code values were as follows. $X_{1}=(A-1500) / 500, X_{2}=(B-2.2) / 1, X_{3}=(C-26.5) / 23.5$. 
TABLE 2 | Box-Behnken experimental design matrix employed by DesignExpert ${ }^{\mathrm{TM}}$ V.10 with experimental results to predict optimum concentrations of medium components.

\begin{tabular}{|c|c|c|c|c|}
\hline \multirow[t]{2}{*}{ Run } & \multicolumn{3}{|c|}{ Design matrix } & \multirow[t]{2}{*}{ Dry biomass (g/L) } \\
\hline & A & B & C & \\
\hline 1 & 1000 & 3.2 & 26.5 & 4.16 \\
\hline 2 & 1500 & 1.2 & 3.0 & 4.26 \\
\hline 3 & 1000 & 2.2 & 50.0 & 4.07 \\
\hline 4 & 2000 & 1.2 & 26.5 & 4.19 \\
\hline 5 & 2000 & 2.2 & 50.0 & 4.21 \\
\hline 6 & 2000 & 3.2 & 26.5 & 4.27 \\
\hline 7 & 1500 & 1.2 & 50.0 & 4.49 \\
\hline 8 & 2000 & 2.2 & 3.0 & 4.18 \\
\hline 9 & 1500 & 2.2 & 26.5 & 5.33 \\
\hline 10 & 1500 & 2.2 & 26.5 & 5.27 \\
\hline 11 & 1500 & 3.2 & 3.0 & 4.33 \\
\hline 12 & 1500 & 2.2 & 26.5 & 5.39 \\
\hline 13 & 1000 & 1.2 & 26.5 & 4.30 \\
\hline 14 & 1000 & 2.2 & 3.0 & 4.09 \\
\hline 15 & 1500 & 2.2 & 26.5 & 5.29 \\
\hline 16 & 1500 & 3.2 & 50.0 & 4.17 \\
\hline 17 & 1500 & 2.2 & 26.5 & 5.33 \\
\hline
\end{tabular}

counted stained and unstained cells. The percentage of viable cells was calculated as the number of unstained cells (live cells) divided by the total number of cells (stained and unstained cells). Measurements were made on three replicates of yeast grown in the different types of medium, and the experiment was repeated three times.

\section{Determination of Protein Carbonylation and Lipid Peroxidation}

Carbonyl content and malondialdehyde (MDA) content were used as indicators of oxidative damage to proteins and lipids, respectively (Chi et al., 2015; Cheng et al., 2016). For the assay of carbonyl content, yeast samples were pulverized in liquid nitrogen. Proteins were extracted from the samples using $500 \mu \mathrm{L}$ of $50 \mathrm{mM} \mathrm{KH}_{2} \mathrm{PO}_{4}$ buffer (pH 7.5) containing $10 \mathrm{mM}$ Tris, $2 \mathrm{mM}$ $\mathrm{MgCl}_{2}, 2 \mathrm{mM}$ EGTA, and $1 \mathrm{mM}$ phenylmethylsulfonyl fluoride. Aliquots of extract were then reacted with $500 \mu \mathrm{L}$ of $10 \mathrm{mM}$ 2,4-dinitrophenylhydrazine (DNPH) dissolved in $2.5 \mathrm{M} \mathrm{HCl}$ or $2.5 \mathrm{M} \mathrm{HCl}$ without DNPH (blank control) in the dark at room temperature with vortexing of the reaction mixture every $15 \mathrm{~min}$ for $1 \mathrm{~h}$. Proteins were precipitated with $20 \%$ (w/v) trichloroacetic acid (TCA) for $10 \mathrm{~min}$ on ice. After centrifugation at $3000 \mathrm{~g}$ for $20 \mathrm{~min}$, protein pellets were washed with ethanol-ethyl acetate $(1: 1, \mathrm{v} / \mathrm{v})$ and dissolved in $6 \mathrm{M}$ guanidine hydrochloride with $20 \mathrm{mM} \mathrm{KH}_{2} \mathrm{PO}_{4}(\mathrm{pH}$ 2.3). Absorbance was recorded at $380 \mathrm{~nm}$ after centrifugation at 9,500 $\mathrm{g}$ for $10 \mathrm{~min}$. The carbonyl content was calculated using the molar absorption coefficient of $22,000 / \mathrm{M} / \mathrm{cm}$ and expressed as nmol per mg protein.

A method based on the reaction of thiobarbituric acid with MDA was used for assaying lipid peroxidation, and detection of thiobarbituric acid-reactive species was determined. Pulverized yeast samples were resuspended in $500 \mu \mathrm{L}$ of $50 \mathrm{mM} \mathrm{KH} \mathrm{PO}_{4}$ buffer ( $\mathrm{pH}$ 6.0) containing 10\% (w/v) TCA and centrifuged at $3,000 \mathrm{~g}$ for $10 \mathrm{~min}$. Supernatants were mixed with $100 \mu \mathrm{L}$ of $0.1 \mathrm{M}$ EDTA and $600 \mu \mathrm{L}$ of $1 \%(\mathrm{w} / \mathrm{v})$ thiobarbituric acid. The reaction mixture was incubated at $100^{\circ} \mathrm{C}$ for $15 \mathrm{~min}$ and subsequently placed on ice for $10 \mathrm{~min}$. After cooling down, absorbance was monitored at $532 \mathrm{~nm}$. The MDA content was calculated using the

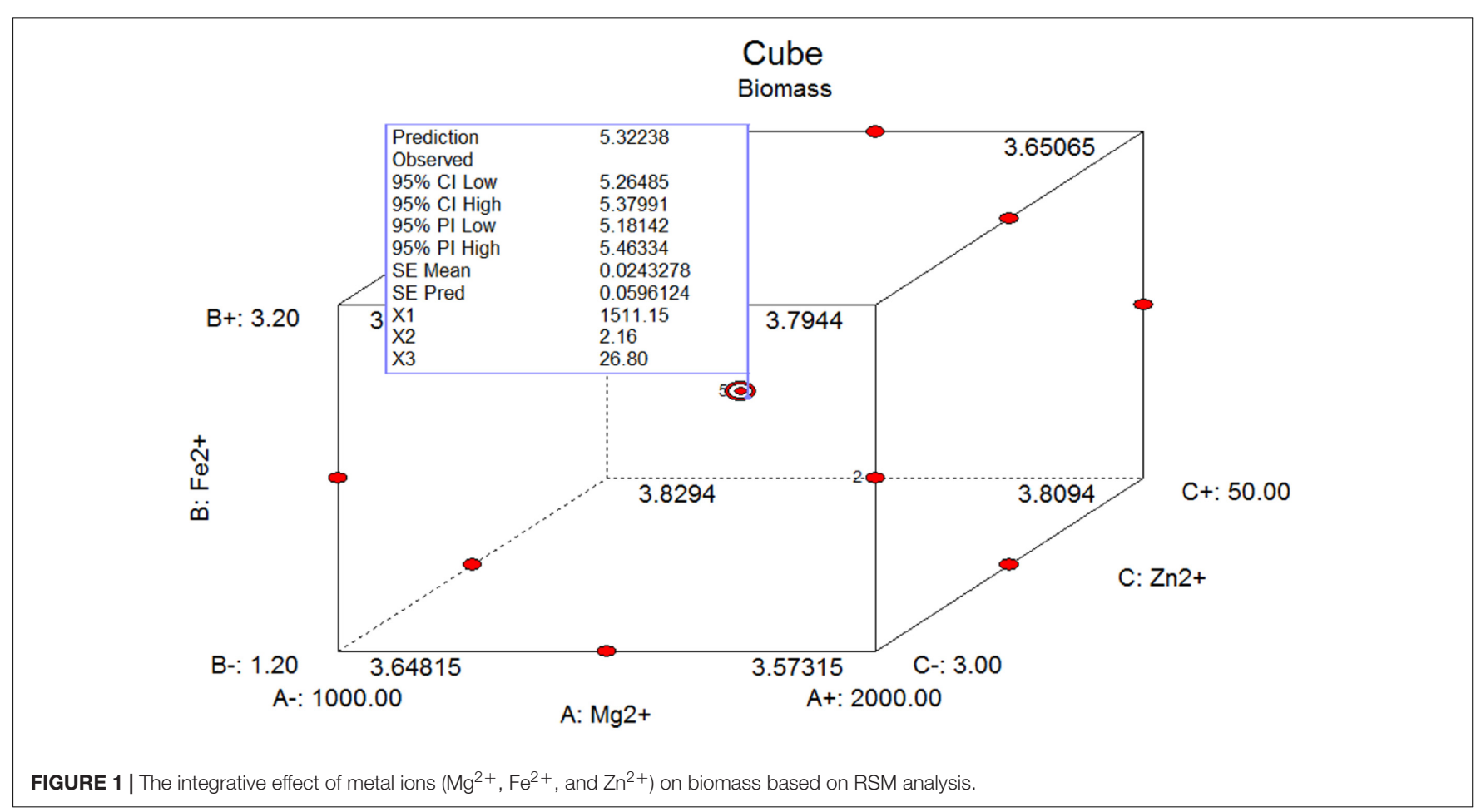



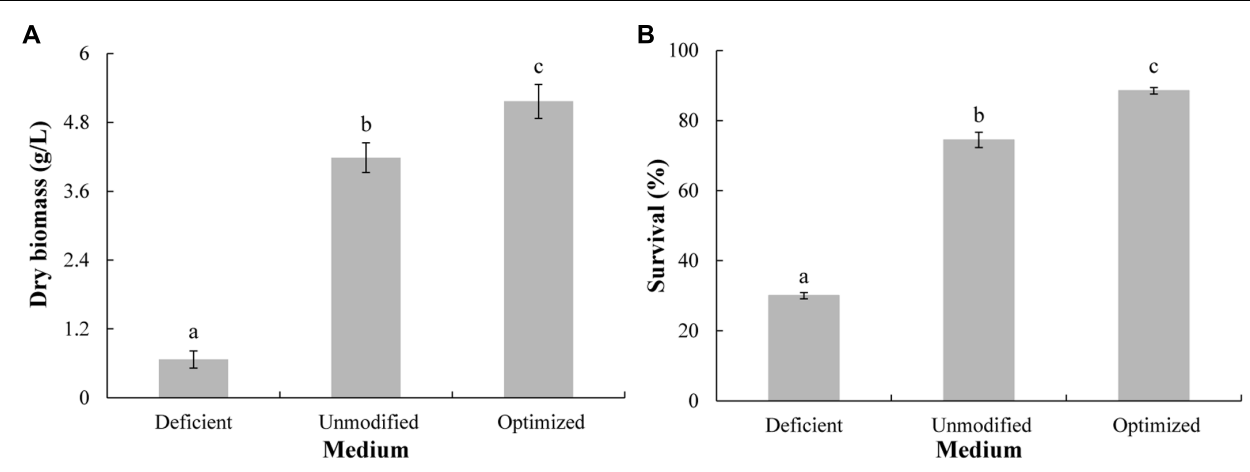

FIGURE 2 | Biomass production (g DW/L) (A) and viability (B) of Candida diversa after 96-h culture in three different media: unmodified minimal mineral (MM) medium, ion-deficient $\mathrm{MM}$ medium, and $\mathrm{Mg}^{2+}, \mathrm{Fe}^{2+}$, and $\mathrm{Zn}^{2+}$ optimized $\mathrm{MM}$ medium. Data represent the mean $\pm \mathrm{SD}$ of the pooled data from three experiments $(n=9)$. Columns with different letters indicate significant differences according to a Duncan's multiple range test $(P<0.05)$.
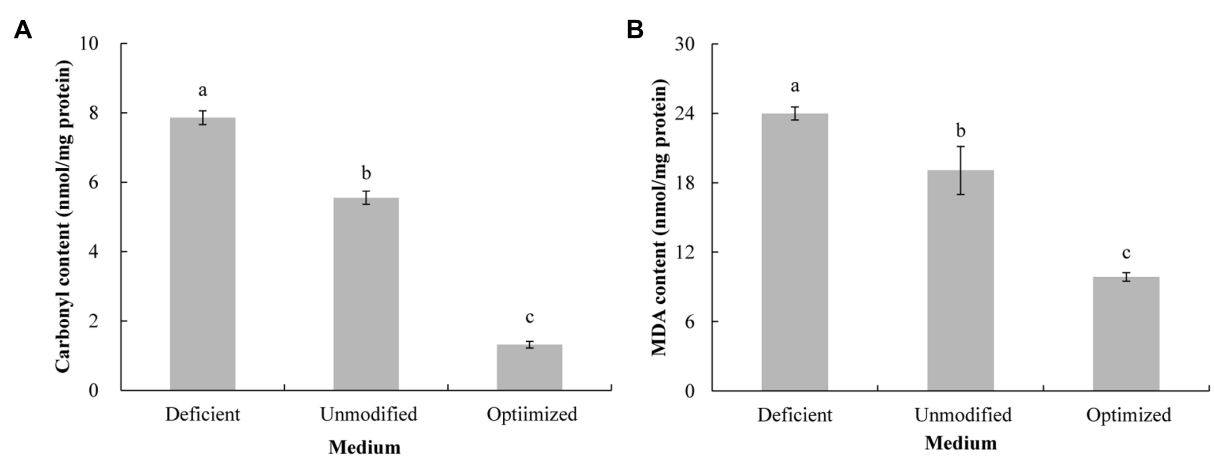

FIGURE 3 | Protein carbonylation (A) and lipid peroxidation (B) in yeast cells of $C$. diversa after 96-h culture in three different media: unmodified MM medium, ion-deficient $\mathrm{MM}$ medium, and $\mathrm{Mg}^{2+}, \mathrm{Fe}^{2+}$, and $\mathrm{Zn}^{2+}$ optimized MM medium. Data represent the mean $\pm \mathrm{SD}$ of the pooled data from three experiments $(n=9)$. Columns with different letters indicate significant differences according to a Duncan's multiple range test $(P<0.05)$.

molar absorption coefficient of $153,000 / \mathrm{M} / \mathrm{cm}$ and expressed as nmol per mg protein (Chi et al., 2015; Cheng et al., 2016). Protein content was measured using the Bradford assay (Bradford, 1976), with bovine serum albumin as a standard. Measurements were made on three replicates of yeast grown in the different types of medium, and the experiment was repeated three times.

\section{Assay of Enzyme Activity}

The extracts prepared from $C$. diversa that were used to determine the antioxidant enzyme activity of glutathione peroxidase (GPX) and superoxide dismutase (SOD) were prepared as previously described (Chi et al., 2015; Cheng et al., 2016), with slight modification. Yeast samples were pulverized in liquid nitrogen and the ground yeast cells were then suspended in chilled potassium phosphate buffer $(0.1 \mathrm{M}, \mathrm{pH} 7.0)$. The cell homogenate from each sample was centrifuged at $10,000 \mathrm{~g}$ for $20 \mathrm{~min}$ at $4^{\circ} \mathrm{C}$, and the supernatant was used for enzyme assay. The enzyme activity of GPX and SOD was assayed using commercial assay kits purchased from Nanjing Jiancheng Bioengineering Institute (Nanjing, China), and expressed as $\mathrm{U}$ per mg protein. One unit of GPX activity was defined as the oxidation of $1 \mu \mathrm{mol} / \mathrm{L}$ reduced glutathione to the oxidized glutathione per minute in the reaction system (Cheng et al., 2016). One unit of SOD activity was defined as the amount of enzyme causing $50 \%$ inhibition in the reduction rate of nitroblue tetrazolium (NBT) (Chi et al., 2015). Protein content was measured using the Bradford assay (Bradford, 1976). Measurements were made on three replicates of yeast grown in the different types of medium.

\section{Biocontrol Assay}

Biocontrol efficacy of $C$. diversa was evaluated as described in a previous study ( $\mathrm{Li}$ et al., 2016). Three wounds (4 mm deep $\times 3 \mathrm{~mm}$ wide) were made on the equator of each fruit. A 5 $\mu \mathrm{L}$ suspension $\left(1 \times 10^{7}\right.$ cells $\left./ \mathrm{mL}\right)$ of $C$. diversa cells was then pipetted to each wound. Fruits were allowed to air dry for $2 \mathrm{~h}$ and then a $5-\mu \mathrm{L}$ spore suspension of $B$. cinerea $\left(1 \times 10^{4}\right.$ spores $\left./ \mathrm{mL}\right)$ was pipetted into each wound. Inoculation with sterile distilled water (no yeast), plus $B$. cinerea spores, served as a control. Treated fruits were placed in a covered plastic food tray, and each tray was enclosed in a polyethylene bag and stored at $25^{\circ} \mathrm{C}$ with an approximate $90 \%$ relative humidity $(\mathrm{RH})$ in a programmable environmental chamber. Disease incidence and lesion diameter of apple fruits were determined after 4 days. Each treatment contained three replicates with 20 fruits per replicate, and the experiment was repeated three times. 

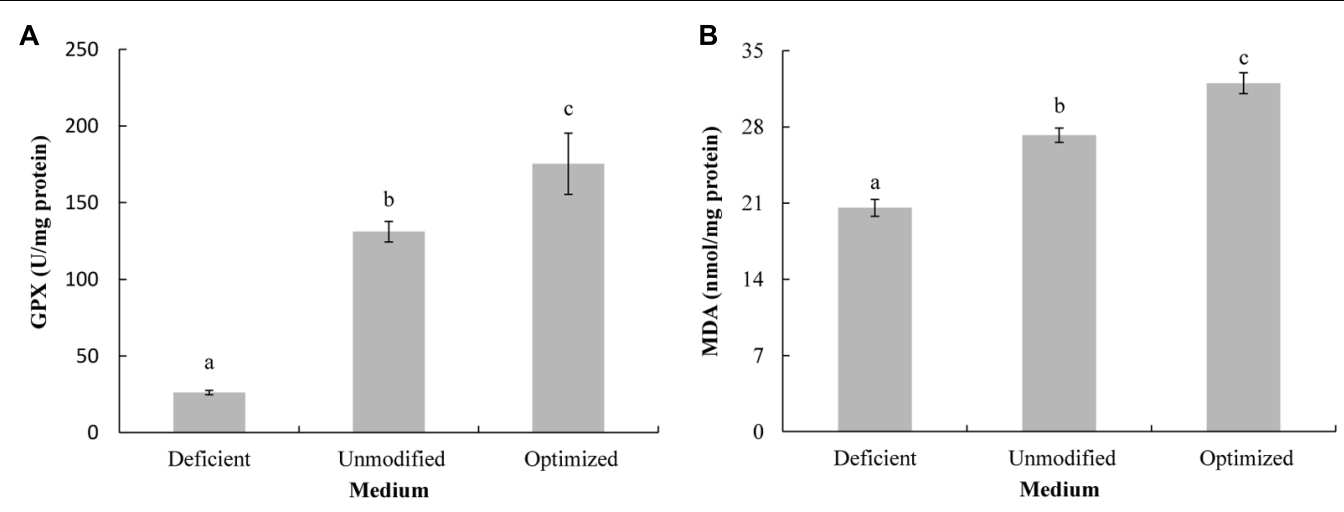

FIGURE 4 | GPX (A) and SOD (B) enzyme activity in yeast cells of $C$. diversa after 96-h culture in three different media: unmodified MM medium, ion-deficient MM medium, and $\mathrm{Mg}^{2+}, \mathrm{Fe}^{2+}$, and $\mathrm{Zn}^{2+}$ optimized MM medium. Data represent the mean $\pm \mathrm{SD}$ of the pooled data from three experiments $(n=9)$. Columns with different letters indicate significant differences according to a Duncan's multiple range test $(P<0.05)$.
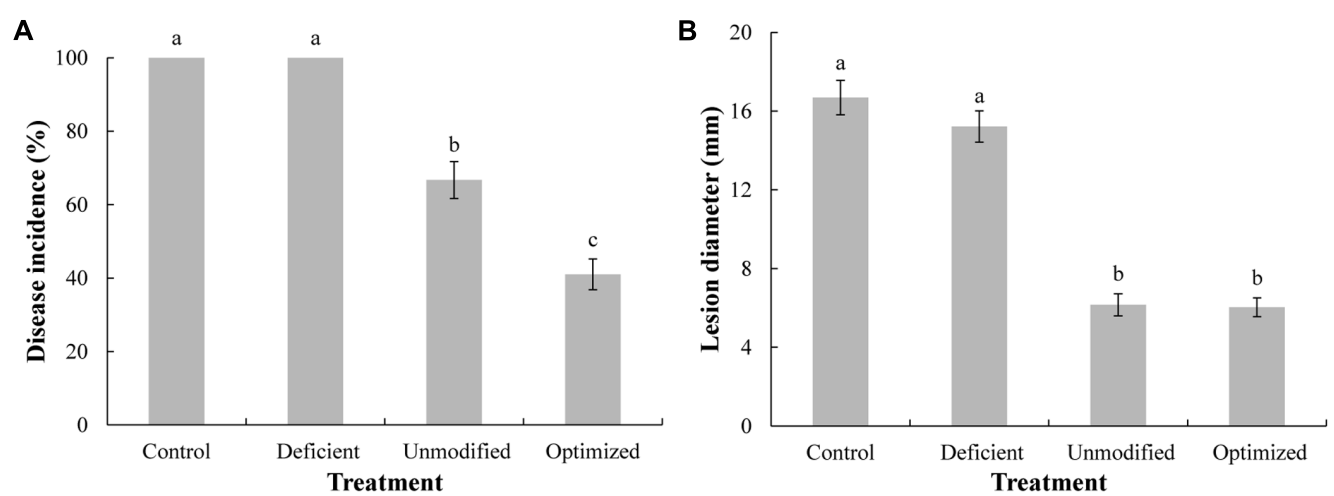

FIGURE 5 | Biocontrol efficacy of $C$. diversa against Botrytis cinerea on apple fruit. Prior to use, yeast were grown for 96-h in three different media: unmodified minimal media (MM), ion-deficient $\mathrm{MM}$, and $\mathrm{Mg}^{2+}, \mathrm{Fe}^{2+}$, and $\mathrm{Zn}^{2+}$ optimized MM. Control: sterile water plus B. cinerea spores, without $\mathrm{C}$. diversa. Disease incidence (A) and lesion diameter (B) in apple fruits were measured 4 days after inoculation. Data represent the mean \pm SD of the pooled data from three experiments $(n=9)$. Columns with different letters indicate significant differences according to a Duncan's multiple range test $(P<0.05)$.

\section{RESULTS AND DISCUSSION}

\section{Optimization of Metal lons in the Medium}

The presence and concentration of metal ions, including magnesium, ferrous and zinc ions, affect microbial biomass production and their microbial metabolism (Kośmider et al., 2012; Hallenbeck et al., 2015; Abd Elrazak et al., 2017). The biomass of $C$. diversa was evaluated in single factor (ion) experiments. Maximum biomass was obtained in each single factor when the concentrations of $\mathrm{Mg}^{2+}, \mathrm{Fe}^{2+}$, and $\mathrm{Zn}^{2+}$ were $1500,2.2$, and $26.5 \mathrm{mg} / \mathrm{L}$, respectively. BoxBehnken experimental design was then used to generate 17 experimental runs varying the concentration of the different metal ions, and the response values were then evaluated (Table 2). The quadratic polynomial equation was generated: $\mathrm{Y}=5.32+0.03 \mathrm{X}_{1}-0.04 \mathrm{X}_{2}+0.01 \mathrm{X}_{3}+0.05 \mathrm{X}_{1} \mathrm{X}_{2}+0.01 \mathrm{X}_{1} \mathrm{X}_{3}-0.1 \mathrm{X}_{2}$ $\mathrm{X}_{3}-0.63 \mathrm{X}_{1}{ }^{2}-0.46 \mathrm{X}_{2}{ }^{2}-0.55 \mathrm{X}_{3}{ }^{2} \quad\left(R^{2}=0.995\right)$. The Model $F$-value of 163.92 indicated that the model was significant, and was confirmed by an ANOVA analysis (Supplementary Table S1). The maximum dry biomass predicted by RSM was $5.32 \mathrm{~g} / \mathrm{L}$, when $1511.15 \mathrm{mg} / \mathrm{L} \mathrm{Mg}^{2+}, 2.16 \mathrm{mg} / \mathrm{L} \mathrm{Fe}^{2+}$, and $26.80 \mathrm{mg} / \mathrm{L}$ $\mathrm{Zn}^{2+}$ were adjusted in the MM medium (Figure 1). Based on the optimization of the medium components, the effect of the optimized medium on the biomass production and viability of $C$. diversa was determined. The unmodified MM and the combined $\mathrm{Mg}^{2+}, \mathrm{Fe}^{2+}$, and $\mathrm{Zn}^{2+}$-deficient MM media served as comparisons.

\section{Effect of Optimized Concentrations of Metal Ions on Biomass Production and Viability}

Relative to the ion-deficient MM and the unmodified MM, the optimized MM produced the greatest dry biomass (Figure 2A), as well as the highest viability level after the 96-h cultivation (Figure 2B). These data indicate that the maximum viable biomass could be obtained in the optimized MM medium. Moreover, the dry biomass obtained in the optimized MM was $5.21 \pm 0.30 \mathrm{~g} / \mathrm{L}$, thus confirming the reliability of determining the composition of the optimized medium by RSM. 


\section{Protein Carbonylation and Lipid Peroxidation}

A certain level of protein and lipid oxidation occur in yeast cells during culturing which has a deleterious effect on the structure and function of proteins and lipids, and a concomitant decrease in viability (Liu et al., 2012; Johansson et al., 2016). Carbonyl content of proteins can be used as an indicator of the level of oxidative damage to proteins (Abegg et al., 2010), while MDA content can serve as an indicator of lipid peroxidation (Li et al., 2010). Comparing the three different types of media, the lowest carbonyl (Figure 3A) and MDA (Figure 3B) levels after 96-h cultivation were observed in yeast cultured in the optimized MM, while the highest levels were present in yeast grown in the ion-deficient MM. These data corresponded well with the results on biomass production and viability of $C$. diversa grown in the three different MM.

\section{Antioxidant Enzyme Activity}

Antioxidant enzyme activity (GPX and SOD) was assessed in order to determine if the lower level of oxidative injury to proteins and lipids was associated with an increase in GPX and SOD activity, due to higher concentration of metal ions in the optimized medium. Amelioration of oxidative damage is partially dependent on the ability of antioxidant enzymes, such as GPX and SOD, to detoxify reactive oxygen species (ROS). These enzymes have been shown to positively contribute to stress adaptation in cultured yeast cells (Liu et al., 2011; Ribeiro et al., 2015; Cheng et al., 2016). In the present study, both GPX (Figure 4A) and SOD (Figure 4B) activity in $C$. diversa grown in optimized MM, was greater than in yeast grown in the other two types of MM (ion-deficient MM and non-modified MM). Antioxidant enzyme activity was lowest in yeast grown in the ion-deficient MM. These data suggest that the optimization of the concentration of metal ions $\left(\mathrm{Mg}^{2+}, \mathrm{Fe}^{2+}\right.$, and $\left.\mathrm{Zn}^{2+}\right)$ enhances antioxidant enzyme activity, thus ameliorating the oxidative damage to proteins and lipids that normally occurs during culturing. Similar results were reported by Wiseman (2005), who indicated that $\mathrm{Fe}^{2+}$ and $\mathrm{Zn}^{2+}$ enhanced SOD and GPX activity in Saccharomyces cerevisiae, and reduced oxidative stress.

\section{Biocontrol Assay}

High levels of viability are advantageous for antagonistic yeasts used as biocontrol agent, where competition for nutrients and space plays a major role in biocontrol activity (Liu et al., 2013a; Wisniewski et al., 2016). As indicated in Figure 5A, the lowest level (percentage) of disease incidence of gray mold on apple fruit was observed in the treatment group utilizing $C$. diversa that had been cultured in optimized MM, followed by yeast grown in unmodified MM. The highest levels of disease incidence were observed with yeast grown in ion-deficient MM, whose level was not significantly different than the non-yeast, control group.

\section{REFERENCES}

Abd Elrazak, A., Ward, A. C., and Glassey, J. (2017). Effect of inorganic salts on bacterial omega-3 PUFA production. Prep. Biochem. Biotechnol. 47, 291-298. doi: $10.1080 / 10826068.2016 .1244681$
Similar results were obtained for lesion diameter (Figure 5B), indicating that $C$. diversa affected both spore germination and germ tube or hyphal development. Notably, C. diversa grown in the ion-deficient MM had no impact on either disease incidence or lesion diameter, relative to the control. This result may have been due to the reduced level of viability in yeast grown in the ion-deficient MM (Figure 2B). These results confirm a previous study on other biocontrol yeasts. In this regard, Liu et al. (2009) reported that the antagonistic yeasts, Cryptococcus laurentii and Pichia membranaefaciens, with higher viability after liquid culture, exhibited better biocontrol performance.

\section{CONCLUSION}

The present study provides information on the enhancement in biomass production, viability, and biocontrol efficacy of the antagonistic yeast, $C$. diversa, by optimization of the composition of the culture medium. Optimized concentrations of $\mathrm{Mg}^{2+}, \mathrm{Fe}^{2+}$, and $\mathrm{Zn}^{2+}$ enhanced the activity of antioxidant enzymes (GPX and SOD) and thus significantly reduced the level of oxidative injury that occurs to yeast cells during culture. The optimized medium allowed for higher biomass production, increased viability, and increased biocontrol efficacy. These results have practical implications for the large-scale production of biocontrol agents.

\section{AUTHOR CONTRIBUTIONS}

YS conceived and designed the experiments. JL and GL performed the experiments. JL analyzed the data. JL and YS drafted the manuscript. All authors read and approved the final manuscript.

\section{ACKNOWLEDGMENT}

This work was supported by National Natural Science Foundation of China (31501688), Natural Science Foundation of Chongqing Science and Technology Commission (cstc2017jcyjAX0401), National Key Research and Development Program of China (2017YFD0201100), and Foundation for High-level Talents of Chongqing University of Arts and Sciences (R2016LX01, R2016TZ02, and P2016LX10).

\section{SUPPLEMENTARY MATERIAL}

The Supplementary Material for this article can be found online at: https://www.frontiersin.org/articles/10.3389/fmicb. 2017.02021/full\#supplementary-material 
Alfenore, S., Molina-Jouve, C., Guillouet, S. E., Uribelarrea, J. L., Goma, G., and Benbadis, L. (2002). Improving ethanol production and viability of Saccharomyces cerevisiae by a vitamin feeding strategy during fed-batch process. Appl. Microbiol. Biotechnol. 60, 67-72. doi: 10.1007/s00253-002-1092-7

Bradford, M. M. (1976). A rapid and sensitive method for the quantitation of microgram quantities of protein utilizing the principle of protein-dye binding. Anal. Biochem. 72, 248-254. doi: 10.1016/0003-2697(76)90527-3

Cheng, Z., Chi, M., Li, G., Chen, H., Sui, Y., Sun, H., et al. (2016). Heat shock improves stress tolerance and biocontrol performance of Rhodotorula mucilaginosa. Biol. Control 95, 49-56. doi: 10.1016/j.biocontrol.2016.01.001

Chi, M., Li, G., Liu, Y., Liu, G., Li, M., Zhang, X., et al. (2015). Increase in antioxidant enzyme activity, stress tolerance and biocontrol efficacy of Pichia kudriavzevii with the transition from a yeast-like to biofilm morphology. Biol. Control 90, 113-119. doi: 10.1016/j.biocontrol.2015.06.006

El Ghaouth, A., Wilson, C. L., and Wisniewski, M. (2003). Control of postharvest decay of apple fruit with Candida saitoana and induction of defense responses. Phytopathology 93, 344-348. doi: 10.1094/PHYTO.2003.93.3.344

Fan, C., Qi, K., Xia, X. X., and Zhong, J. J. (2013). Efficient ethanol production from corncob residues by repeated fermentation of an adapted yeast. Bioresour. Technol. 136, 309-315. doi: 10.1016/j.biortech.2013.03.028

Hallenbeck, P. C., Grogger, M., Mraz, M., and Veverka, D. (2015). The use of design of experiments and response surface methodology to optimize biomass and lipid production by the oleaginous marine green alga, nannochloropsis gaditana in response to light intensity, inoculum size and CO2. Bioresour. Technol. 184, 161-168. doi: 10.1016/j.biortech.2014.09.022

Jernejc, K., and Legiša, M. (2002). The influence of metal ions on malic enzyme activity and lipid synthesis in Aspergillus niger. FEMS Microbiol. Lett. 217, 185-190. doi: 10.1111/j.1574-6968.2002.tb11473.x

Johansson, M., Chen, X., Milanova, S., Santos, C., and Petranovic, D. (2016). PUFA-induced cell death is mediated by Ycalp-dependent and -independent pathways, and is reduced by vitamin C in yeast. FEMS Yeast Res. 16:fow007. doi: $10.1093 /$ femsyr/fow007

Kośmider, A., Białas, W., Kubiak, P., Drożdżyńska, A., and Czaczyk, K. (2012). Vitamin B12 production from crude glycerol by Propionibacterium freudenreichii ssp. shermanii: optimization of medium composition through statistical experimental designs. Bioresour. Technol. 105, 128-133. doi: 10.1016/ j.biortech.2011.11.074

Li, G., Chi, M., Chen, H., Sui, Y., Li, Y., Liu, Y., et al. (2016). Stress tolerance and biocontrol performance of the yeast antagonist, Candida diversa, change with morphology transition. Environ. Sci. Pollut. Res. 23, 2962-2967. doi: 10.1007/ s11356-015-5769-8

Li, H., Wang, H. L., Du, J., Du, G., Zhan, J. C., and Huang, W. D. (2010). Trehalose protects wine yeast against oxidation under thermal stress. World J. Microbiol. Biotechnol. 26, 969-976. doi: 10.1007/s11274-009-0258-1

Liu, J., Sui, Y., Wisniewski, M., Droby, S., and Liu, Y. (2013a). Review: Utilization of antagonistic yeasts to manage postharvest fungal diseases of fruit. Int. J. Food Microbiol. 167, 153-160. doi: 10.1016/j.ijfoodmicro.2013.09.004

Liu, J., Sui, Y., Wisniewski, M., Xie, Z., Liu, Y., You, Y., et al. (2017). The impact of the postharvest environment on the viability and virulence of decay fungi. Crit. Rev. Food Sci. Nutr. doi: 10.1080/10408398.2017.1279122 [Epub ahead of print].

Liu, J., Tian, S. P., Li, B. Q., and Qin, G. Z. (2009). Enhancing viability of two biocontrol yeasts in liquid formulation by applying sugar protectant combined with antioxidant. BioControl 54, 817-824. doi: 10.1007/s10526-009-9229-6

Liu, J., Wisniewski, M., Artlip, T., Sui, Y., Droby, S., and Norelli, J. (2013b). The potential role of PR- 8 gene of apple fruit in the mode of action of the yeast antagonist, Candida oleophila, in postharvest biocontrol of Botrytis cinerea. Postharvest Biol. Technol. 85, 203-209. doi: 10.1016/j.postharvbio.2013.06.007
Liu, J., Wisniewski, M., Droby, S., Norelli, J., Hershkovitz, V., Tian, S., et al. (2012). Increase in antioxidant gene transcripts, stress tolerance and biocontrol efficacy of Candida oleophila following sublethal oxidative stress exposure. FEMS Microbiol. Ecol. 80, 578-590. doi: 10.1111/j.1574-6941.2012.01324.x

Liu, J., Wisniewski, M., Droby, S., Vero, S., Tian, S., and Hershkovitz, V. (2011). Glycine betaine improves oxidative stress tolerance and biocontrol efficacy of the antagonistic yeast Cystofilobasidium infirmominiatum. Int. J. Food Microbiol. 146, 76-83. doi: 10.1016/j.ijfoodmicro.2011.02.007

Mari, M., Di Francesco, A., and Bertolini, P. (2014). Control of fruit postharvest diseases: old issues and innovative approaches. Stewart Postharvest Rev. 1, 1-4. doi: 10.2212/spr.2014.1.1

Marín, A., Cháfer, M., Atarés, L., Chiralt, A., Torres, R., Usall, J., et al. (2016). Effect of different coating-forming agents on the efficacy of the biocontrol agent Candida sake CPA-1 for control of Botrytis cinerea on grapes. Biol. Control 96, 108-119. doi: 10.1016/j.biocontrol.2016.02.012

Melin, P., Schnürer, J., and Håkansson, S. (2011). Formulation and stabilisation of the biocontrol yeast Pichia anomala. Antonie Van Leeuwenhoek 99, 107-112. doi: 10.1007/s10482-010-9522-5

Poreda, A., Tuszyński, T., Zdaniewicz, M., Sroka, P., and Jakubowski, M. (2013). Support materials for yeast immobilization affect the concentration of metal ions in the fermentation medium. J. Inst. Brew. 119, 164-171. doi: 10.1002/jib.77

Ribeiro, T. P., Fernandes, C., Melo, K. V., Ferreira, S. S., Lessa, J. A., Franco, R. W., et al. (2015). Iron, copper, and manganese complexes with in vitro superoxide dismutase and/or catalase activities that keep Saccharomyces cerevisiae cells alive under severe oxidative stress. Free Radic. Biol. Med. 80, 67-76. doi: 10.1016/j.freeradbiomed.2014.12.005

Spadaro, D., and Droby, S. (2016). Development of biocontrol products for postharvest diseases of fruit: the importance of elucidating the mechanisms of action of yeast antagonists. Trends Food Sci. Tech. 47, 39-49. doi: 10.1016/j.tifs. 2015.11.003

Stehlik-Tomas, V., Zetić, V. G., Stanzer, D., Grba, S., and Vahčić, N. (2004). Zinc, cooper and manganese enrichment in yeast Saccharomyces cerevisiae. Food Technol. Biotechnol. 42, 115-120.

Sui, Y., Wisniewski, M., Droby, S., and Liu, J. (2015). Responses of yeast biocontrol agents to environmental stress. Appl. Environ. Microbiol. 81, 2968-2975. doi: 10.1128/AEM.04203-14

Wiseman, A. (2005). Avoidance of oxidative-stress perturbation in yeast bioprocesses by proteomic and genomic biostrategies? Lett. Appl. Microbiol. 40, 37-43. doi: 10.1111/j.1472-765X.2004.01624.x

Wisniewski, M., Droby, S., Norelli, J., Liu, J., and Schena, L. (2016). Alternative management technologies for postharvest disease control: the journey from simplicity to complexity. Postharvest Biol. Technol. 122, 3-10. doi: 10.1016/j. postharvbio.2016.05.012

Yang, Q., Zhang, H., Zhang, X., Zheng, X., and Qian, J. (2015). Phytic acid enhances biocontrol activity of Rhodotorula mucilaginosa against Penicillium expansum contamination and patulin production in apples. Front. Microbiol. 6:1296. doi: $10.3389 /$ fmicb.2015.01296

Conflict of Interest Statement: The authors declare that the research was conducted in the absence of any commercial or financial relationships that could be construed as a potential conflict of interest.

Copyright (c) 2017 Liu, Li and Sui. This is an open-access article distributed under the terms of the Creative Commons Attribution License (CC BY). The use, distribution or reproduction in other forums is permitted, provided the original author(s) or licensor are credited and that the original publication in this journal is cited, in accordance with accepted academic practice. No use, distribution or reproduction is permitted which does not comply with these terms. 